\title{
“¡Ándate, pájaro, antes que viva y te mate!”. La muerte en la escritura de Gonzalo Millán
}

\author{
Edson Faúndez V. ${ }^{1}$ y María Luisa Martínez M. ${ }^{2}$
}

Resumen. Este artículo se centra en el estudio de las significaciones que adopta la muerte en la escritura de Gonzalo Millán, uno de los poetas claves de la generación de 1960 en Chile. El análisis, que privilegia el comentario de textos, despliega una mirada sobre su producción poética, aunque enfatiza los sentidos que adoptan la escritura diarística, el cuerpo enfermo y la inminencia de la muerte en Veneno de escorpión azul. Diario de vida y de muerte (2007).

Palabras clave: poesía chilena; diario íntimo; enfermedad; hospitalidad.

[en] “¡Ándate, pájaro, antes que viva y te mate!” (Go, bird, before I live and kill you!) Death in Gonzalo Millán's writing

Abstract. This article focuses on the study of the meaning that death adopts in Gonzalo Millán's writing, one of the key poets of the 1960 generation in Chile. The analysis, which favours commentary on texts, displays a view of his poetic production, though it emphasises the meanings that diaristic writing, the sick body, and the imminence of death adopt in Veneno de escorpión azul. Diario de vida y de muerte (2007) (Blue scorpion venom. Diary of life and death).

Keywords: Chilean poetry; diary; sickness; hospitality.

Sumario: 1. “¡Ándate, pájaro, antes que viva y te mate!”. 2. "El Signo de la Calavera”. 3. "Una hurna humeante junto a una guadaña". 4. "Muero creyendo que voy a una fiesta y no al matadero".

Cómo citar: Faúndez V., E. y Martínez M., Ma.L. (2021) “¡Ándate, pájaro, antes que viva y te mate!”. La muerte en la escritura de Gonzalo Millán, en Anales de Literatua Hispanoamericana 50, 225-235.

\section{1. “AÁndate, pájaro, antes que viva y te mate!”}

El sujeto en Relación personal (1968) "vive en el tiempo y en sus relaciones con el tiempo y con las cosas, con el mundo cotidiano que lo rodea, lo que los poemas pretenden develar, sólo que el suyo es un mundo privado y más o menos doméstico" (Morales, 2009: 29). La experiencia del tiempo que se manifiesta en lo cotidiano, y que Leonidas Morales establece como signo distintivo de la generación de poetas de 1960, trae como correlato, entre otros problemas, la certidumbre de que todo se encamina inexorablemente hacia la ruina y la podredumbre. Así lo evidencian, sólo por nombrar algunos, los poemas "Historieta del blanco niño gordo y la langosta", "En blancas carrozas, viajamos", "Toco rondas infantiles con una mueca en los labios" y "Hago señas y signos pasajeros", donde la sonrisa del niño se transfigura en el gesto tal vez incomprensible ante la fragilidad del ser (la langosta) y el acontecimiento de la muerte ${ }^{4 ;}$ donde el descubrimiento de la

\footnotetext{
1 Universidad de Concepción. Chile.

E-mail: efaundez@udec.cl

${ }^{2}$ Universidad de Concepción. Chile

E-mail: marmartinez@udec.cl

${ }^{3}$ Según Javier Campos, Relación personal se caracteriza porque en él "la infancia está concebida como una etapa mutilada; todas las relaciones que establece el adolescente, que es también la continuidad esperpéntica de la niñez, devienen relaciones feístas con el tú-mujer, conflictivas con los espacios juveniles inmediatos y hostilmente distanciadas de la ciudad" (1987: 39).

${ }^{4}$ En este mismo sentido puede leerse el poema "Consuelo", que textualiza la ironía que reside en la visión de la presencia de la muerte trabajando en la vida, así como el absurdo de la vanidad.: "Si pensara que en tu cuerpo, / ya perdido, y tu belleza, / el coto de la muerte crece, / mi preocupación sería, creo, / para llorar de pura risa" (1968: 42).
} 
sexualidad implica también una forma de relación con la muerte (cifrada en el significante "polvo"); donde "un muñeco podrido bajo tierra" envía a la presencia de la muerte en una escritura que admite en sus paisajes los restos, los residuos del cuerpo y sus deseos poblados por devenires animales; y donde se reconoce el carácter pasajero de la palabra socavada por la muerte.

"Bautismo de polvo" es un texto donde el sujeto que juega "como los gorriones / con el polvo de los siglos", es decir con el libre fluir del tiempo no racionalizado, advierte la presencia de la muerte en sí mismo y "en segundos encanece" (1997: 32). Los comentarios críticos de Claudio Guerrero (2015) contribuyen a visualizar en este poema, y en otros de los primeros años de la escritura de Millán las bodas que el poeta establece con la otredad por excelencia, que marcan al sujeto a partir de la prematura vejez y de una serie de visiones signadas por el deterioro de la vida. El rostro del sujeto anciano, que reaparecerá -inducido por potencias diferentes- en La ciudad (1979), el primer libro del exilio voluntario y forzado en Canadá ${ }^{\text {, remite }}$ a la disolución de la frontera que separa en territorios antitéticos vida y muerte. El sujeto se posiciona así en una zona en la que los heterogéneos se reúnen. ¿No expresa esto acaso la confusión entre el "silencio del muerto" y el "grito del recién nacido" del poema "Tu quebrado vidrio rojo" (1968: 25) del escritor que ya en sus primeros textos siente que sólo puede hacer señas y construir signos pasajeros? Gonzalo Millán responde a la muerte en su primer libro con huellas-palabras que cubren el polvo, testigo también de las metamorfosis del placer, con una sonrisa irónica o una risa que se confunde con el llanto ${ }^{6}$. El otro rostro que no cesa de desplegarse desde Relación personal hasta Veneno de escorpión azul está hundido "dentro de la tierra" (1968: 41), trae "la manta de la obscuridad" (1968: 48) del poema "Eclipse" y porta las heridas que los jotes incansables producen, “AÁndate, pájaro, antes que viva y te mate!” (1968: 45). Hay en la escritura poética de Gonzalo Millán una relación personal, estética y ética, con la muerte. Es posible por ello advertir su conjura y elisión, su cautiverio y soberanía, su fascinación y repudio en los territorios que instaura la palabra de este poeta fundamental de la lírica chilena de la segunda mitad del siglo XX.

\section{2. "El Signo de la Calavera"}

Vida, antología publicada en Canadá en 1984, reúne poemas escritos entre 1968 y 1982. Algunos de sus textos, como "Vida" y "Apocalipsis doméstico", intensifican en la escritura de Millán lo que María Zambrano llama en Filosofía y poesía "la melancolía funeraria de las hermosas apariencias" (2006: 38). "Apocalipsis doméstico" puede leerse, entre otras posibilidades, como un texto que produce un "poetacronista", quien ilumina los problemas del exilio que se exacerban en el espacio familiar (Nómez, 2010); o como un texto ecfrástico que produce la "imagen móvil, que va cambiando de foco, paso a paso, en este recorrido por el interior y el exterior de la casa" (Zaldívar, 1998: 180), y que exige, al igual que una sinestesia, la participación de todos los sentidos del lector. Los deteriorados objetos de la casa, según Zaldívar, se constituyen en uno de los signos de muerte del poema; en efecto, sujeto y cosas articulan un bloque de afectos caracterizado por el desmoronamiento del espacio familiar y la inminencia de la muerte, que el poema revela en dos versos claves: "la peineta perdió otro diente. / La trizadura del espejo es otra arruga" (Millán, 1997: 86). La relación con las cosas y con lo viviente, que permite que emerja la pesadez del tiempo inexorable, traza la línea fronteriza en la que se posiciona el habitante, quien deviene en sujeto fantasmal de un territorio que no puede ser hospitalario.

Los objetos que establecen sólo una relación funcional y de estatus con los habitantes de la ciudad le permiten al poeta textualizar, desde una entrada distinta, los efectos negativos del "neoliberalismo" y del consecuente "reino del mercado" (Sepúlveda, 2013: 193), productor de desigualdad, de injusticia y del debilitamiento de los sueños colectivos desplegados en décadas anteriores. El refrigerador devenido en catafalco blanco ("Promisión") y el automóvil devenido en silla de ruedas ("Limousine"), sólo por señalar los que parecen más significativos, establecen el predominio del "Signo de la Calavera" ("Wheel Wrench"). Cuatro versos de "Esplendoroso día" permiten amplificar lo expuesto: "Y lava, encera, acaricia / como no

\footnotetext{
${ }^{5}$ Gonzalo Millán, entrevistado por Pacián Martínez, declara: “mira, así como la decisión de salir fue en parte voluntaria y en parte forzada, también la decisión de volver tiene las mismas características, impuesta por lo que considero mi deber" (1882: 5).

${ }^{6}$ Waldo Rojas en "Gonzalo Millán: acerca de su poesía reunida" destaca la importancia del humor y de la ironía en los primeros poemas del escritor chileno: "Sabiduría también en el modo cómo la carga emotiva sedimentada por la experiencia juvenil, magma bullente de sentimientos contradictorios, se cristalizaba y se inervaba en el verso, siguiendo la exacta filigrana de una expresión hecha de fraseos fruiciosos, cadencias insinuantes, inquietantes conclusiones de un humor socarronamente candoroso y de una ironía acerba" (1997: 14).
} 
acariciará nunca / a su mujer ni a sus hijos / el necrófilo, su automóvil” (Millán, 1997: 162). El amor al otro viviente ha sido sustituido por el amor a los objetos que en nada se aproximan a las cosas portadoras de la memoria de los ancestros, a las cosas vívidas y no funcionales, atesoradas, por ejemplo, en la escritura poética de Jorge Teillier, heredero del pensamiento poético de Rainer María Rilke, quien sabe que el poeta es el guardián de una alianza secreta con las cosas. La relación del sujeto con las cosas en la escritura de Millán se singulariza por un "excedente de sentido" (Bodei, 2013) que, en el caso previamente mencionado, adquiere un carácter negativo. Las cosas, separadas de su función pragmática, son investidas de una carga negativa que ilumina el derrumbe multidimensional del sujeto, quien experimenta, al igual que las cosas regidas por la ley de obsolescencia, la dolorosa sensación de la finitud, la inminencia de la muerte en el acontecimiento del eclipse de la relación positiva del sujeto con las cosas y, consecuentemente, del sujeto con la vida. La distancia insuperable del hombre y las cosas establece así la crisis de una época, de un sistema económico, de una relación con la temporalidad, así como también del sujeto y del lenguaje.

La imposibilidad de la actualización del deseo irresistible de ir hacia el otro viviente, de convertir su alteridad en un acontecimiento del sujeto, que disuelva la individualidad y condicione el ejercicio de la libertad a la respuesta que debe darse siempre al otro que puede habitarnos, es tal vez la crítica descarnada a una sociedad refractaria a la ternura, la piedad, la justicia, la amistad y el amor. La leyenda atroz que el encuentro con el "Signo de la Calavera" hace evidente remite, por consiguiente, al deterioro de la vida, amplificado hasta el hartazgo por los emisarios de la muerte violenta dentro del marco de las sociedades de consumo: "el carnicero lee un diario ensangrentado / mientras por la calle marchan soldados" (Millán, 1997: 148). Escribir significa así producir otros signos que le permitan al poeta resistir y desplegar una promesa que se traduzca en la lucha contra las fuerzas regidas por el hombre necrófilo: "A la poesía lego / la imagen póstuma / de mi corazón martillando / como un puño de brasa / el refrigerador del infierno" (Milán, 1997: 152). Los trayectos estéticos se hacen, por lo mismo, más intensos en La ciudad y en Virus (1987), libros que la crítica especializada no puede examinar sin la consideración de las tensiones lingüísticas que revelan el incremento del deseo de elaborar una lengua que intenta, aunque "la mordaza impide el habla" (Millán, 1997: 200), sacudirse las consignas del régimen de muerte de la calavera dictatorial; o la gestación, como se desprende de Virus, de una escritura que "reflexiona sobre las condiciones que hacen posible el oficio del poeta" (Foxley, 1994: 131). El lenguaje, en efecto, "está contaminado" (1997: 244). Los poetas de la generación de 1960 lo saben desde el inicio de su quehacer poético, certidumbre que se agudiza "por el solo hecho de referir a una atmósfera infestada [se refiere al Chile de la dictadura]" (Bianchi, 1990: 123). El poeta devenido anciano/anciana, el poeta sobreviviente, alza su voz heterogénea y colectiva para componer un poema que procura exorcizar las potencias aliadas de quien ejerce de manera absoluta y autoritaria el poder: "cerdo", "pedazo de mierda", "muerto en vida". El poeta en La ciudad", libro estilísticamente no comprendido por Ignacio Valente $(1980)^{8}$, afecta el lenguaje y encuentra en procesos de hibridación y en la perturbación de la sintaxis las estrategias para que la memoria de la muerte y la memoria de la vida se transfiguren en verdaderas armas no sólo contra el olvido, sino también contra la injusticia: "Un cambio de sintaxis invierte el curso del río. / Un punto detiene la ciudad" (Millán, 1997: 269). La derivación estética de Virus (1987) llevará al poeta hacia la gestación de lo que él considera "una nueva lengua" (Millán, 1997: 327) a la que se accede mediante una intensificación del devenir sobrio del lenguaje, que busca crear pasajes de vida, característico de su escritura. Sus poemas breves, escritos con "un alfabeto de microbios" (Millán 1997: 288), son "vacunas" contra la aflicción de los moribundos, a la vez que edifican una nueva

${ }^{7}$ La ciudad (1979) es uno de los libros más comentados de Gonzalo Millán. Carmen Foxley y Magda Sepúlveda iluminan en sus respectivas lecturas algunos de los signos distintivos (ejercicio autoritario del poder, emergencia de la barbarie del mercado, cotidianeidad, vulnerabilidad del exiliado) de uno de los textos fundamentales del exilio chileno. Carmen Foxley señala que La ciudad se constituye en "un relato hecho de fragmentos proposicionales que reconstituyen, imaginariamente, el escenario de la vida de la ciudad que se ha dejado atrás. Esos fragmentos se cruzan con otros que sugieren la atmósfera de la ciudad del exilio, lugar desde el cual se evocan, ordenan y analizan las condiciones de una cotidianeidad que se empeña en la sobrevivencia y el trabajo, a pesar de la irregularidad de la situación circunstancial. Porque allí el poder se impone, controla, maltrata y vigila a diario a aquellos que se refugian en la privacidad, pero escapan a1 sobresalto, la represión, las penurias, la escasez económica, ni tampoco a la frivolidad que contagia el mercado y la publicidad, que junto a1 autoritarismo rigen la vida de la ciudad" (1994: 133). Magda Sepúlveda escribe en Ciudad quiltra. Poesía chilena (1973-2013): "la ciudad imaginada es la urbe chilena tras la Doctrina de Seguridad Nacional (1964) diseñada por Estados Unidos, en el contexto de la Guerra Fría, y con el propósito de evitar que los comunistas se tomaran el poder" (2013: 188) y "Millán crea un personaje que escribe La ciudad. En la primera edición era un anciano, pero en la última de Cuarto Propio es una anciana. El cambio de género acentúa el punto de debilidad del exiliado, mediante la feminización de los agredidos, tratamiento que está también en Purgatorio de Zurita" (2013: 189).

${ }^{8}$ Ignacio Valente califica el libro de Millán como "monótono y aburrido" (El Mercurio, 1980: E3). El recurso de la repetición, dominante en La ciudad, y que lleva a Valente a plantear dicho juicio, ha sido estudiado por Felipe Cussen en el artículo "La repetición es el nuevo principio creativo' (Gonzalo Millán) / 'I see repetition as a basic creative method' (Dirk Huelstrunk)” (2015). 
hospitalidad para acoger amorosamente al otro: "Llegar a escribir / algún día / con la simple / sencillez del gato / que limpia su pelaje con un poco de saliva" (Millán, 1997: 302). El deseo de escribir con "la simple / sencillez del gato" remite, por un lado, a una reflexión metapoética sobre los procesos de desterritorialización estética de la poesía; remite, por otro lado, a la síntesis con lo heterogéneo animal, que le permite al poeta acceder a las potencias de la fragilidad y la ternura, capaces de lidiar contra el odio imperante en la red social ${ }^{9}$.

Nadie puede aniquilar el recuerdo de un país destruido por la violencia del hombre por el hombre, eso pareciera sugerir La ciudad. Nadie puede dejar que el poeta, quien, como se lee en "Conclusión sobre la firma" de Virus, lleve un 11 grabado en su apellido, que lo "separa en dos, en un antes y un después, / en un aquí y allá" (1997: 336), continúe escuchando "el estertor del moribundo" (Millán, 1997: 242). Nadie puede impedir que el poema devenga en escritura de la herida, "Los vencedores están heridos de muerte [...] La herida los traiciona. / La herida denuncia a los hipócritas" (Millán, 1997: 273); pero también en escritura que produce una ventana utópica a partir de la cual vuelven a surgir los sueños del porvenir y la esperanza para la propia escritura que busca la forma de su actualización en un contexto afectado por potencias hostiles a la vida: "Mientras palpita el corazón existe la vida. / La dictadura es reversible. / No perdurará la dictadura [...] Árbol de la esperanza. / Creciendo al borde. / Del abismo. Con la mitad. De las raíces al aire. / ¡Mantente firme!" (Millán, 1997: 280) ${ }^{10}$.

\section{3. "Una hurna humeante junto a una guadaña"}

Óscar Galindo ha señalado que la escritura poética de Gonzalo Millán "puede, en un sentido amplio, ser leída como una poética de la mirada, pero es la publicación de Claroscuro (2002) la expresión más compleja y sistemática de esta retórica en la poesía chilena contemporánea" (2007: 110). El fructífero diálogo intertextual que se produce, agrega Galindo, entre Millán y las obras barrocas de Caravaggio y Zurbarán ilumina el carácter metapoético y autorreflexivo del libro, que permea sin duda toda la producción literaria del poeta, a la vez que ilumina una obra signada por la "ampliación de los soportes del discurso poético [y por] el cuestionamiento de las posibilidades de representación de lo real por parte de los discursos artísticos y en una desestabilización de las disciplinas y soportes que más allá de la palabra le aseguran su existencia en el sistema cultural" (2007: 121). Claro/Oscuro, además de lo señalado, se caracteriza por la irrupción temática y lingüística de un cuerpo-escritura desarticulado, cercenado (como en santa Águeda) o desorganizado, que posibilita el encuentro de heterogéneos tales como Eros y Tánatos, placer y sufrimiento, belleza y horror, y la posibilidad de un sujeto que, si bien se despliega a partir de la mirada fascinada por las pinturas de Caravaggio y Zurbarán, en realidad se singulariza por el desplazamiento desde lo otro retenido en la mirada hacia la emergencia de los signos definitorios de su intimidad. Poeta-Narciso que encuentra en la diferencia de su reflejo los múltiples y transparentes rostros que lo habitan: "Yo soy la imagen que jamás se borra, / soy el reflejo sobre las eternas aguas" (Millán, 2002: 52). Pero las aguas eternas y la imagen del poeta-Narciso, rehén de la diferencia, fluyen sólo en los territorios creados por los pintores barrocos: "Regresar al cuadro / buscando siempre nuestro reflejo / como si la pintura fuera la sombra / fascinante de un ojo de agua" (Millán, 2002: 53). La reterritorialización del sujeto y la posibilidad del descubrimiento de sus rostros se producen, al parecer, en la imagen-escritura que surge en las zonas intermedias que se actualizan entre el propio sujeto y las obras pictóricas que él contempla y en las que se contempla. Doble desplazamiento. Doble afecto: poeta de la mirada que por su mirada es contemplado: poeta que se mira en las imágenes que surgen con el hallazgo de analogías: "Me miro, me estoy mirando en mi hazaña, / en el éxito de la semejanza perfecta" (Millán, 2002: 61); poeta, por lo tanto, que se descubre a sí mismo en el acontecimiento de lo otro: "el rostro que miro es mi propia firma en el agua" (Millán, 2002: 65).

Uno de los rostros del sujeto, el rostro tocado por la muerte, surge de su encuentro con la pintura San

\footnotetext{
${ }^{9}$ Soledad Bianchi escribe a propósito de lo que considera la identificación hombre-animal en la poesía de Millán: “animal con el que el ser humano se identifica por su semejante debilidad e impotencia frente al conquistador" (1990: 127).

${ }^{10}$ Los versos arriba citados pertenecen al poema "Árbol de esperanza", que Millán publica por primera vez en Seudónimos de la muerte (1984) y, posteriormente, se incluye, con variaciones, en La ciudad. Recogemos la versión de Trece lunas (1997). Enoc Muñoz sugiere en “ ¡Mantente firme! Gonzalo Millán: poema y resistencia” (2007) que uno de los sentidos del texto excede la lectura fundada en las circunstancias históricas y que la resistencia desplegada puede advertirse a partir de la emergencia de una escritura "que se dirige a sí en la espera de sí" (Disponible en: https://web.uchile.cl/vignette/cyberhumanitatis/CDA/texto_simple2/0,1255,SCID\%253D21063\%2526ISID\%253D731,00.html).
} 
Jerónimo en meditación de Caravaggio. La síntesis entre meditación y muerte, evidente por la presencia del signo de la calavera, es clave en el poema ecfrástico de Millán. La certidumbre que acompaña la interrogación que adviene en la escena de la meditación del santo (y del poeta) es la misma que advertimos en el poema "El pensador de Rodin" de Gabriela Mistral: "el Pensador se acuerda que es carne de la huesa" (1960: 13). Millán escribe, eso sí, "El cráneo sobre los libros trae a tierra" (Millán, 2002: 70), retomando la metáfora tierra-muerte, que, en este caso, se impone al saber humano, ya presente en algunos poemas de Relación personal. La muerte es el exceso ingobernable figurado en la capacidad de mirar que distingue la muerte respecto del sujeto, posicionándola en un territorio donde no alcanza la fragilidad de la mirada del sujeto textual: "La muerte mira lo que no puede ver, / la muerte mira lo que no puede leer" (Millán, 2002: 85). La paralizante certidumbre de la imposibilidad de mirar del sujeto lo desplaza hacia el ámbito sensorial de la escucha ${ }^{11}$. El poeta ante la certidumbre de la finitud y el descubrimiento de la fragilidad de la mirada sólo puede escuchar, como indica "Mochuelo", el enigmático y aterrador canto de la muerte: "me quedo escuchando / el grito del mochuelo" (Millán, 2002: 91).

En Autorretrato de memoria (2005) el poeta "ahora cuenta sus recuerdos, / las limosnas de la memoria / como un avaricioso mendigo" (Millán, 2005: 15). Una de las claves de lectura del libro, por lo mismo, es el recuerdo que se transfigura en un verdadero despertar del sujeto como se lee en "Autorretrato recordando". El poema, tocado por los efectos del despliegue de la memoria, instaura territorios en los que son visibles las incesantes desapariciones de los vivientes y de las cosas, de sensibilidades y de órdenes (sociales) distintos. El poema se convierte en mausoleo de la memoria que acoge el oscurecido espacio de la muerte de los otros. La escena del encuentro imaginario con la muerte "vestida con largas ropas de mujer" (Millán, 2005: 37) de "Autorretrato con calavera" permite advertir cómo el "niño nonato", sentado "en las rodillas huesudas" (37) de la muerte, se siente ingrávido y leve, produciéndose así la exorcización de los signos terribles de la muerte. Resultan de gran interés, en este sentido, las sugestiones que despliega el epígrafe de Gustave Flaubert del poema "Yacente”: “¿Qué necrópolis es el corazón humano! ¿Para qué visitar los cementerios? Abramos nuestros propios recuerdos ¡Cuántas tumbas!”. El corazón humano está poblado de muertos y recordar es liberar a los difuntos de sus tumbas, a la vez que crear el espacio de una hospitalidad: el corazón es así una necrópolis que garantiza el intercambio entre vivos y muertos.

El sujeto de la memoria-mausoleo, "la roja sanguijuela de la muerte" (Millán, 2005: 40), "empleado de una funeraria" (Millán, 2005: 28), dibuja, pues, su autorretrato a partir del murmullo de la muerte que lo posee y le enseña sus verdaderos rostros. Su configuración destaca, entre otros aspectos, por sus trayectos, que revelan el nomadismo del sujeto y su exposición constante a la mutación que adviene del encuentro con lo otro. El poeta se presenta, en efecto, como "adicto a los viajes" (Millán, 2005: 23), que se iniciarán en el desaparecido Cine Recoleta, como "hijo errante" (Millán, 2005: 44) y como quien huye de las zonas consagradas por el poder ${ }^{12}$.

El autorretrato que escribe la memoria de la muerte a partir de una serie de desplazamientos y de encuentros en la necrópolis del corazón señala algo más: la disolución del sujeto-rostro individual, grávido y molar. Así se desprende de uno de los "Autorretratos numerados", el "\#500 (Como miles)" para ser más exactos, donde el sujeto, sin nombre y sin rostro ya, se singulariza por su transfiguración mediante el encuentro con lo múltiple y lo heterogéneo: "No vengo de la unión de dos cuerpos/ Procedo de muchos y voy hacia ellos. / Soy grande, pequeño, alto, bajo, / Gordo, flaco, cobrizo, negro, blanco. / Somos uno solo sin nombre y sin rostro. / Aquí me llamo miles" (Millán, 2005: 41). El autorretrato del poeta surge sobre la base de la exposición de una interioridad, de una desnudez y de un secreto, y exponer quiere decir acá hacer aparecer el yo a partir de la síntesis entre la mismidad y las alteridades, entre las semejanzas y las diferencias. Una mancha, una ausencia o el vacío ocupan el lugar del rostro, que se convierte, sin embargo, en llamado y posibilidad de visitación -lo que nos recuerda los planteamientos éticos desarrollados por Emmanuel Levinas en Totalidad e infinito (2006)-. Si el sujeto es algo en sus desapariciones, que podemos homologar a las disoluciones de lo viviente, es gracias a su exposición, a su desnudez, a su retiro y a su transfiguración en acontecimiento de lo otro. De ahí que la imagen del sujeto sea inseparable de la imagen de literatura que se produce en el estilo de Autorretrato de Memoria. Si seguimos a Jean-Luc Nancy, quien en La mirada del retrato advierte que "el retrato pone a la muerte misma en obra: la muerte obrando en plena

\footnotetext{
${ }^{11}$ Es importante señalar que, como lo indica Javier Campos, en Relación personal Millán era fundamentalmente un poeta táctil. Los desplazamientos, entonces, se ordenan desde lo táctil hacia lo visual y lo auditivo.

${ }^{12}$ El carácter desacralizador de la escritura poética inicial de Millán puede relacionarse con esta alusión de Autorretrato de memoria. Javier Campos señala que Relación personal se singulariza por “desacralizar el tema de la infancia” (1987: 41).
} 
vida, en plena figura y en plena mirada" (Millán, 2005: 54), entonces es posible sostener que en la escritura de Millán sujeto y lenguaje están regidos por el obrar de la muerte. El sujeto que se arranca el rostro para mostrar su intimidad toda y se expone a lo heterogéneo que adviene desde otro lugar acoge en su corazón las desapariciones (incluso las nuestras, incluso la suya), pero ya no tiene poder sobre sí mismo, sus trayectos y mutaciones. Los otros que lo habitan y lo someten a diversos estados posicionan por ello al sujeto en el no saber, como se hace patente en "Autorretrato en el laberinto de la Catedral de Amiens", poema que cierra el libro.

Gabinete de papel se caracteriza, entre otros aspectos, por la sobriedad que signa el tratamiento del lenguaje, el despliegue de una escritura autorreflexiva, la transfiguración del poeta en "coleccionista y curador" (Garrido, 2015), la creación de territorios que posibilitan el diálogo entre disciplinas artísticas, la emergencia de un yo que experimenta desplazamientos y transfiguraciones en los territorios que crea el poema $^{13}$, la relación del poeta con los objetos que adquieren un excedente de sentido por su condición de artísticos y la articulación de una máquina de escritura que funciona conectada a una máquina de observación de la realidad. Estos dos últimos rasgos del libro plasman su singularidad en la medida en que es factible sostener que Gabinete de papel se edifica sobre la base de una máquina de observación de una realidad acotada a una serie de objetos artísticos. De ahí la relevancia del poema "Puerta metálica", donde la máquina de observación ilumina un objeto vulgar, no tocado por la sensibilidad del artista, cuya presencia produce una herida en el poeta: "El borde del fierro mal soldado / y con óxido de la puerta me persigue. / No sé por qué me hirió el mirarlo" (Millán, 2011: 69). Gonzalo Millán erige, pues, sus poemas y su vida a partir de una relación estética con los objetos artísticos.

La muerte descubre la mentira y el absurdo encubiertos por la vanidad en Gabinete de papel. Eso es lo que enuncia el poema "Apuntes para una vanitas", que concluye con un verso que revela el destino de todos los vivientes: "una hurna humeante junto a una guadaña" (Millán, 2011:55). La presencia de la muerte en el libro se encuentra asociada fundamentalmente a la temporalidad: "Dammi tempu ca ti perciu / 'Dadme tiempo y te perforaré' / la dice el ratón a la nuez / en su dialecto siciliano. / El tiempo nos repite lo mismo" (Millán, 2011: 36); a la relación entre Eros y Tánatos: "Moriré o la venceré y viviré / para morir otro día en sus brazos" (Millán, 2011: 43); a las iluminaciones que surgen de la recepción estética del arte: "La ciudad fue conmovida por una negra procesión / de muertos, moribundos y calaveras / montadas en esqueléticos cabellos" (Millán, 2011: 75); a la enfermedad y la cesura que establece entre vivos y muertos, textualizada en el poema "Hay sólo dos países" de Diario de muerte (1989) de Enrique Lihn'", y su captura dentro del marco del sistema hospitalario: "Mientras los sanos fabulan males imaginarios / el enfermo asiste a la escuela del sufrimiento" (Millán, 2011: 73), "No hay diferencia de calor entre la cánula / y la fosa, los fórceps y las pinzas de biopsia" (Millán, 2011: 73).

La práctica artística, como sugerimos previamente, se convierte en una de las estrategias de resistencia ante los efectos de la inminencia de la muerte. Así lo advierte "Animal planet (Naturalia)", poema donde el poeta deviene alondra, antílope y gacela que a través del canto y de perfectos movimientos engaña y huye de la muerte portadora de las fierezas del azor y del león: "La alondra se salva del azor /porque mientras se eleva canta / prodigando su canción / desafiante y melodiosa. / El antílope que brinca más alto / y las gacelas más ágiles / no conocerán aún la hora del león” (Millán, 2011: 77). El poeta escribe en Gabinete de papel para eludir las celadas de la muerte. Lo mismo hará, en una clave estilística distinta, en Veneno de escorpión azul. Diario de vida y de muerte (2007).

\section{4. "Muero creyendo que voy a una fiesta y no al matadero"}

Veneno de escorpión azul, libro que textualiza la lucha que establece el poeta con un cáncer pulmonar, es un diario literario e íntimo ${ }^{15}$, por lo que edifica un espacio lingüístico propicio para la emergencia del yo. La

\footnotetext{
${ }^{13}$ El yo emerge en poemas tales como "Noctámbulos /Edward Hopper", "Estudios ultramarinos", "Santa Úrsula", "La flor que planté en el espejo", "Kakemono de la cascada", "Hotel Las Rocas de Maitencillo", "La visita", "Glifo maya".

${ }^{14}$ Los primeros versos del poema de Enrique Lihn son los siguientes: "Hay sólo dos países: el de los sanos y el de los enfermos / por un tiempo se puede gozar de doble nacionalidad / pero, a la larga, eso no tiene sentido" (1989: 27).

${ }^{15}$ Seguimos la definición de Georges Gusdorf sobre diario íntimo, simplificada por Manuel Hierro del siguiente modo: "la noción diario íntimo, en cambio, la aplicamos teniendo en cuenta dos importantes premisas. Históricamente se han considerado diarios íntimos todos aquellos escritos que no están destinados a la publicación hasta la muerte del autor, con independencia del grado de introspección que puedan contener. La acepción «journal intime», o diario íntimo, la tomamos prestada de Georges Gusdorf, quien establece una separación entre este tipo de diarios y el
} 
estructura textual del diario considera, según la síntesis de los signos distintivos del diario realizada por Manuel Hierro, el tiempo presente en el que escribe el diarista, la intimidad desplegada y la identidad personal. La conexión de estos tres elementos "va a permitir entender el diario íntimo como estructura textual y espacio de significación reflexiva donde se construye la subjetividad desde y en la costumbre y el decurso de los días" (Hierro, 1999: 105). La construcción de la subjetividad del sujeto textual adopta, respecto de la relación con la vida del diarista, siempre un carácter ambivalente, pues el diario puede articularse sobre la base de elementos ficcionales y factuales, como lo ha señalado Álvaro Luque, quien sigue los planteamientos desarrollados por Enric Bou en "El diario: periferia y literatura":

El diario se lee entonces desde coordenadas ficcionales, puesto que el Yo emplea las mismas estrategias para autoconstruirse en un texto ficcional que en otro factual, y también desde el pacto autobiográfico de Lejeune, en tanto que el lector lee una verdad; una verdad que además puede entenderse transmitida por el autor voluntariamente. El diario, que desde este punto de vista ya es literario, se sitúa así en un terreno que es el propio de la literatura en la medida en que conviven el plano real y el ficcional (2016: 302).

Elementos ficcionales y factuales se requieren para iluminar los diversos niveles y matices que van a dibujar los (eventualmente) múltiples rostros del yo. La reflexión teórica respecto del diario permite advertir una tensión relevante en su filiación o distanciamiento de la escritura autobiográfica ${ }^{16}$. Consideraremos la escritura diarística como escritura del yo, que no puede explicarse únicamente por la tensión entre un status a-literario (privado) y un status literario (público), según la tesis desarrollada por Hans Rudolf Picard en "El diario como género entre lo íntimo y lo público" (1981); sin embargo, la escritura del diario no se agota en la efervescencia de un yo que da forma a su propia interioridad sufriente (Sontag, 2005), que desea vivir y tener una personalidad (Girard, 1963), sino que irradia hacia los otros, independientemente de los efectos de la publicación y la circulación. Hay, por lo tanto, una otredad irreductible en el mismo momento en que el diarista recoge con sinceridad sus dislocados fragmentos de vida. El diario, además de lo previamente mencionado, posee un carácter abierto y fragmentario (Didier, 1976; Luque, 2016); se constituye en una escritura híbrida, heterogénea, inconclusa, que encuentra en su relación con el otro, a quien conjura y espera, y con el tiempo uno de sus más sugerentes sentidos. Maurice Blanchot ha señalado en El libro que vendrá que el diario "está sometido a una cláusula de apariencia liviana pero terrible: debe respetar el calendario. Este es el pacto que sella. El calendario es su demonio, el inspirador, el compositor, el provocador y el guardia" (1992: 207) ${ }^{17}$. El diarista y su escritura se encuentran prisioneros del tiempo; por lo tanto, la práctica escritural encuentra en la conciencia de la finitud, de la mortalidad del yo, uno de sus signos distintivos. Se escribe desde el presente, capturando el flujo de la vida en el fluir disonante de una escritura libérrima, pero siempre aguardando lo que adviene desde el otro tiempo, desde el tiempo del futuro, que la escritura niega y afirma al mismo tiempo, porque el diario "está dicho bajo la salvaguardia del acontecimiento; eso pertenece a los asuntos, a los incidentes, al comercio del mundo, a un presente activo, a una duración quizás absolutamente nula e insignificante, pero al menos sin retorno, trabajo de lo que se adelanta, va hacia mañana, y va definitivamente" (Blanchot, 2000: 23).

El diario de Millán presenta rasgos de las definiciones teóricas sobre la escritura diarística que hemos procurado revelar en pocas líneas, entre los que resaltan la efervescencia del yo, el diseño híbrido y abierto, la síntesis entre lo fictivo y lo real, la apertura hacia el otro y el imperativo temporal, que despliega una relación con la inminencia de la muerte propia. Veneno de escorpión azul captura, en algunas ocasiones, el pasado lejano, lo que perturba la doxa que establece que el pasado inmediato es el tiempo del diario y el pasado lejano es el tiempo de la autobiografía. El tránsito hacia el otro tiempo intensifica la producción de líneas de fuga creativas y liberadoras de un sujeto que experimenta la inminencia de la muerte en su cuerpo invadido por el cáncer y en el cuerpo de la escritura regida por el inclemente demonio del calendario ${ }^{18}$.

El sujeto en Veneno de escorpión azul se posiciona en una zona de indeterminación, entre la vida y la

denominado «journal externe». El diario externo acarrea en su escritura unas determinadas marcas: las anotaciones dan más importancia al acontecimiento que al sujeto, y, en muchas ocasiones, es una crónica del mundo y de los otros más que un relato del yo del diarista [...] Por el contrario, el diario íntimo, propiamente dicho, y según una de las definiciones que deslinda Gusdorf, es la forma de escrito más apta para facilitar el conocimiento exacto en el dominio de la vida personal, pues salvaguarda la espontaneidad de la experiencia vivida" (1999:114).

${ }^{16}$ Jean-Louis Déotte señala en La época de los aparatos una diferencia fundamental entre el tiempo de los relojes y el tiempo de los calendarios: "El tiempo de los relojes es el tiempo cuantitativo de la ciencia, en el que un instante no se distingue de otro. Al contrario de ese continuum, los calendarios ponen en relación la temporalidad y la nominación (la memoria) [por lo que producen una emancipación del tiempo que] supone una puesta en escena, actores, espectadores" (2013: 60-61). Los planteamientos de Déotte son sin duda valiosos y obligan a pensar de qué modo la temporalidad del calendario se despliega en los diarios.

${ }^{17}$ Respecto de este problema puede consultarse también La découverte de soi de Georges Gusdorf (1948).

${ }^{18}$ La escritura de Veneno de escorpión azul, asimismo, dialoga intertextualmente con la escritura precedente de su autor, si consideramos, por ejemplo, que un libro como Autorretrato de memoria (2005) se enmarcaría dentro de lo que hemos llamado escritura del yo. Así lo ha estudiado Biviana Hernández (2008), quien examina la configuración de la identidad del sujeto de dicho libro a partir de los vínculos que la escritura de Millán establece con la autobiografía, la memoria y el autorretrato. 
muerte, donde surgen, fluyen y se conectan sensaciones, estados y rostros de condición diversa: “¿Dónde te ubicas, más acá de la muerte o más allá de la vida" (Millán, 2008: 287); en la que el cuerpo frágil y vulnerable del yo errante se estremece y vacila ante la muerte próxima: "Vacilo en la deriva inerte" (Millán, 2008: 209). Línea de frontera en la que la subjetividad del sujeto es arrastrada por afectos que lo hacen sentir el horror de la soledad de los moribundos, "miedo, sí, a morir solo, sin una mano y sin los ojos amados, sin aquellas palabras que indican y muestran el camino" (Millán, 2008: 222); la necesidad imperiosa de "una salvación sin motivo" (Millán, 2008: 272); el hambre de arrancar de cuajo los dominios del "pulpo" inmisericorde del cáncer; e incluso las consecuencias de la aceptación de la muerte: "iQue salte la marioneta del esqueleto" (Millán, 2008: 302).

Macarena Roca en "Hibridación genérica en Gonzalo Millán. Lectura del diario íntimo Veneno de escorpión azul" (2007) aborda el texto, fundamentalmente, a partir del concepto de rizoma desarrollado por Gilles Deleuze y Félix Guattari. Su lectura destaca que la escritura de Millán representa la muerte irrepresentable mediante su corporalización, objetualización y marcas que remiten al tiempo de lo cotidiano. Tesche y Sancho señalan, por otro lado, que Millán "escribe como una manera de sobrevivir [...] El lenguaje es, para la voz poética, una forma de recuperar el control del cuerpo [...] La respuesta que encuentra Millán es habitar en su propia escritura. Su cuerpo se convierte en la escritura misma" (2012: 110-111). La emergencia del cuerpo, que vincula al sujeto a un aquí y a un ahora, es clave en una escritura que se constituye en un gesto de resistencia ante la inminencia de la muerte. Así lo testimonian fragmentos que remiten a la imagen del yo poseído por la diferencia radical impuesta por la enfermedad y a la imagen de la fragilidad del cuerpo que atestigua en sí mismo los efectos de su resistencia: "Soy un enfermo terminal en el umbral de la muerte" (Millán, 2008: 29), "El veneno del escorpión azul y el cáncer pelean en mis pulmones" (Millán, 2008: 35), "Estoy herido de muerte" (Millán, 2008: 63), "Soy cacharro roto de greda" (Millán, 2008: 74), "Me huelo, Huelo mal" (Millán, 2008: 99). La escritura del diario de vida y de muerte articula, sin embargo, una relación indisoluble entre el cuerpo y la interioridad de un sujeto que despliega una meditación y preparación para la muerte. Escribir un diario en el umbral del encuentro con el instante supremo e intransferible de la muerte puede entenderse como una de las tecnologías del yo que, según Michel Foucault, "permiten a los individuos efectuar, por cuenta propia o con la ayuda de otros, cierto número de operaciones sobre su cuerpo y sobre su alma, pensamientos, conducta, o cualquier forma de ser, obteniendo así una transformación de sí mismos con el fin de alcanzar cierto estado de felicidad, pureza e inmortalidad" (Foucault, 2000: 48) ${ }^{19}$. Veneno de escorpión azul despliega así una serie de operaciones sobre el cuerpo y sobre el alma que permiten una resistencia a la idea de cesación que impone la muerte: "quisiera retardarlo, frenarlo o anularlo" (Millán, 2008: 267), "todavía puedo resistir y aguantarme" (Millán, 2008: 276); pero, al mismo tiempo, posibilita el pensamiento de la acogida de la muerte: "Moriré, muero creyendo que voy a una fiesta y no al matadero" (Millán, 2008: 46), "No saco nada con resistirme / con negarme al violento desalojo, llegará el anunciado / día inevitable de la mudanza" (Millán, 2008: 249).

Las formas de resistencia ante la muerte son, en realidad, formas de exorcización del terror que implica la muerte. Su eficacia consiste precisamente en esta posibilidad de sustraer cuerpo y alma a la violencia arrebatadora de la muerte: "Quisiera tratar a la muerte sin miedo, sin rencor, sin faltarle el respeto" (Millán, 2008: 31). Entre las operaciones conducentes a vencer el terror de la muerte se encuentra nombrarla. Nombrar la muerte encierra una serie de variantes en la que la negatividad se subvierte por el deseo de acogida, formas de relación del poeta con la muerte que pueden comprenderse sobre la base de una tensión y no a partir de la idea de transformación de la idea de negatividad. Los siguientes ejemplos, que articulan una especie de diccionario íntimo portador de los nombres de la muerte, son esclarecedores en este sentido: "un parpadeo a otra escala" (Millán, 2008: 32), "fracaso" (Millán, 2008: 44), "mancha de nacimiento / inexplicable" (Millán, 2008: 46), "una falsa calle sin salida, una puerta fuera de quicio" (Millán, 2008: 77), "La muerte partera / la comadrona velada del pueblo" (Millán, 2008: 93), "disfrazada de mucama servicial, de enfermera fiel, de monja piadosa, compasiva, caritativa" (Millán, 2008: 140), "la puta maldita" (Millán, 2008: 141),“La Pelada" (Millán, 2008: 231), "Flaca delincuente” (Millán, 2008: 245), "La mansa muerte, la indomable muerte" (Millán, 2008: 245), "la muerte imperial" (Millán, 2008: 261).

Otras formas de resistencia ante la muerte son la lectura, la evocación de los amigos, lo que envía a lo que

\footnotetext{
${ }^{19}$ Manuel Hierro advierte esta relación entre el diario y las tecnologías del yo descritas por Foucault: “el diario íntimo está consagrado a la cultura de la conciencia de sí que ya practicaban en la antigüedad griegos y romanos, y que a lo largo de la historia ha ido ofreciendo cimas literarias como el diario de Franz Kafka, André Gide, Stendhal entre muchos otros" (1999: 123).
} 
Norbert Elías llama una "resonancia sentimental" (2009: 134), y el deseo de compañía, aludido en reiteradas ocasiones por el poeta, que crea una especie de comunidad fundamental para hacer tolerables los diversos estados por los que atraviesa el enfermo y el moribundo: dos rostros claves en la representación del sujeto. Discursivamente es relevante, junto a la imaginación y "el humor, el mal humor, la ironía" (Millán, 2008: 246), la memoria de lo insignificante. La "nimiedad", la menudencia, lo nimio, los detalles cotidianos, se revelan como una de las estrategias axiales en la escritura. Forma del placer que estalla incluso en el instante en que el sufrimiento pareciera ejercer su poderío. El "placer de la escritura minuciosa" (Millán, 2008: 190), del instante y del detalle, capaz de albergar un suspiro de eternidad, permite el arribo de la ilusión en los territorios de la desesperanza, porque "Dios está en el detalle como también un fractal, como los átomos de los hologramas" (Millán, 2008: 61).

Veneno de escorpión azul es un libro que puede leerse del modo en que el mismo autor lo propone, como "una herencia póstuma o la bitácora de una travesía milagrosa, una expedición salvadora, saludable, protectora" (Millán, 2008: 255). El diario del poeta que concibió la lengua como instancia "regeneradora" y que fue, dentro del marco de su generación, el "más atraído por el vértigo de las orillas y su vacío irrespirable" (Rodríguez, 2002: 106) preserva y duplica los cortes que realiza el escritor sobre lo insignificante y cotidiano, conjurando una salvación. Maurice Blanchot destaca precisamente este rasgo salvífico de la escritura diarística:

Se escribe para salvar la escritura, para rescatar su vida mediante la escritura, para rescatar su pequeño yo (las represalias que se toman contra los demás, las maldades que se destilan) o para salvar su gran yo dándole aire, y entonces se escribe para no perderse en la pobreza de los días, o, como Virginia Woolf, como Delacroix, para no perderse en ese tormento que es el arte, que es la exigencia sin límite del arte" (1992: 210).

Millán pareciera escribir para salvar su vida mediante la escritura; para preservar y duplicar los instantes que rescata desde lo insignificante cotidiano; para no sucumbir ante la atroz certidumbre que gobierna a quien se acerca "a la cama de piedra, al altar terrible, desnudo" (Millán, 2008: 319). Millán "anhela restituir con la escritura el discurrir de un presente desvanecido o a punto de desvanecerse" (Hierro, 1999: 116); insiste en autorrepresentar su yo acosado por la muerte: ejercicio escritural que se transfigura en una donación al otro, en la medida en que su influencia irradia más allá del tiempo de la enunciación.

Veneno de escorpión azul se inscribe dentro de un marco histórico-social signado por lo que, como sugiere Philippe Ariès, ya se insinuaba en La muerte de Iván Ilich (1886) de León Tolstoi, a saber: "la creciente repugnancia a admitir abiertamente la muerte -la suya y la del otro-, el aislamiento moral impuesto al moribundo por esa misma repugnancia y la ausencia de comunicación que de ello resulta, y por último la medicalización del sentimiento de la muerte" (2016: 251). Norbert Elias es elocuente respecto de la expulsión de la alteridad de la muerte en las sociedades actuales, las que "empujan a los moribundos y a la muerte cada vez más fuera de la vista de los vivos, a esconder estos hechos tras las bambalinas de la vida normal en las sociedades más desarrolladas. Jamás anteriormente ha muerto la gente de una manera tan poco ruidosa y tan higiénica como hoy en día en este tipo de sociedades y jamás lo ha hecho en unas condiciones que hayan fomentado tanto la soledad" (2009: 132). Veneno de escorpión azul ilumina y hace audible, en efecto, precisamente aquello que el entramado social desea mantener en la oscuridad y en el silencio: los signos de la intolerable muerte. La escritura de Millán se convierte así, dentro de este marco general, en una morada habitada por el poeta enfermo, por el poeta moribundo, y por los seres que ingresan en el ámbito de sus afectos. Por eso leemos en su diario: "A medida que el tiempo se acorta, / vivo cada vez más en la lengua" (Millán, 2008: 146). Es la patria hospitalaria de la lengua la que le permite al poeta algo que le está prácticamente vedado en los dispositivos hospitalarios, porque "El hospital es la puerta de la cárcel, de la muerte" (Millán, 2008: 17). Nos referimos a la posibilidad de hablar con los otros y de seguir siendo parte de una comunidad: "Mis guachos queridos: no lloren ni me añoren. Recuérdenme como uno de ustedes. Pensemos que quizás empecemos una amistad nueva. Mírenme como el corresponsal de una dimensión simultánea, que supera la división muerte-vida. (Eso sí, no me jodan el espíritu)" (Millán, 2008: 227). El moribundo invita a sus "guachos queridos" a soñar una "amistad nueva", la que supone la inclusión del difunto. Sólo puede cruzar el umbral vida-muerte, pareciera sugerir Millán, quien es acogido en una nueva comunidad, donde la diferencia de los muertos no sea expulsada.

Gonzalo Millán señala otro de los sentidos posibles de su escritura: "Escribir Veneno de escorpión azul es hacer algo antes de morir, luchar por tu vida" (Millán, 2008: 40). El poeta escribe para resistir, para abrir pasajes de vida, para hacer algo antes del advenimiento del acontecimiento de la muerte. Ese hacer algo envía, como ya lo propusimos, a la posibilidad de hablar del moribundo, negada por la institución médica, como advierte Jean Baudrillard, quien entiende que la enfermedad debe poseer una estructura de 
intercambio: "Los sueros y los laboratorios, la curación, no es más que la coartada de la prohibición de hablar" (1980: 215); "Exigencia aberrante e inadmisible del enfermo (y del moribundo) de fundar un intercambio en esta diferencia; exigencia no de hacerse cuidar y corregir, sino de dar su enfermedad, y que sea recibida, por lo tanto, simbólicamente reconocida e intercambiada, en vez de ser neutralizada en la muerte técnica hospitalaria y en esa supervivencia estrictamente funcional que se llama la salud y la curación" (1980: 216). La medicina alternativa (el veneno del escorpión azul, las galletas de marihuana) le escamotean a los dispositivos hospitalarios la manipulación técnica del cuerpo del enfermo de cáncer: "Soy un Enfermo con máyúscula, con E. / Con todas las de la ley, con E mayúscula. / Condenado, sentenciado a aceptar lo inaceptable" (Millán, 2008: 271). Pero es el gesto de la escritura de un diario que "siempre quedará trunco" (Millán, 2008: 168), en definitiva, lo que desliza una potencia que puede erosionar la relación que nuestras sociedades utltratecnologizadas y ultrahigiénicas mantienen con la enfermedad, con el moribundo y con la muerte. La transgresión de la "prohibición de hablar" busca abrir pasajes de vida signados por el rechazo a la exorcización del habla, que posibilitó tantos trayectos estéticos y hallazgos existenciales desde Relación Personal hasta el momento de la escritura regida por el calendario; y busca "dar la enfermedad", dirigirla a los "condenados que esperan la muerte" (Millán, 2008: 47), como una donación en la que resaltan los luminosos túneles que comunican vida y muerte.

\section{Referencias bibliográficas}

Ariès, Philippe (2016). Morir en Occidente. Desde la Edad Media hasta nuestros días. Buenos Aires: Adriana Hidalgo Editores.

Baudrillard, Jean (1980). El intercambio simbólico y la muerte. Caracas: Monte Ávila Editores Latinoamericana.

Bianchi, Soledad (1990), "La poesía de Gonzalo Millán (Atención al detalle y concentrada intensidad)", Atenea, $\mathrm{n}^{\circ}$. 461, págs. 115-154.

Blanchot, Maurice (2000). El espacio literario. Barcelona: Editorial Paidós.

-------, ----- (1992). El libro que vendrá. Venezuela: Monte Ávila Editores.

Bodei, Remo (2013). La vida de las cosas. Buenos Aires: Amorrortu.

Bou, Enric (1996), "El diario: periferia y literatura", Revista de Occidente, vols. 182-183, págs. 121-136.

Campos, Javier (1987). La joven poesía chilena en el período 1961-1973 (G. Millán, W. Rojas, O. Hann). Minneapolis/Concepción: Institute for the Study of Ideologies and Literature/Ediciones Literatura Americana Reunida.

Cussen, Felipe (2015), "La repetición es el nuevo principio creativo (Gonzalo Millán), Trans, no. 19. Disponible en: https://journals.openedition.org/trans/1200\#authors

Didier, Béatrice (1976). Le journal intime. Paris: Presses Universitaires de France.

Déotte, Jean-Louis (2013). La época de los aparatos. Buenos Aires: Adriana Hidalgo Editora.

Elías, Norbert (2009). La soledad de los moribundos. México: Centzontle/Fondo de Cultura Económica.

Foucault, Michel (2000). Tecnologías del yo y otros textos afines. Barcelona: Ediciones Paidós.

Foxley, Carmen (1994), "Lo móvil, efímero y abierto: La ciudad de Gonzalo Millán”, en Gonzalo Millán. La ciudad (2a. ed.). Santiago: Cuarto Propio, págs. 129-144.

Galindo V, Oscar (2007), "Palabras e imágenes, objetos y acciones en la postvanguardia chilena", Estudios Filológicos, (42), págs. 109-121.

Garrido, Rolando (2015), "El gabinete como diálogo interartístico. Gonzalo Millán coleccionista, curador y postproductor de visualidad escrita", Universum, vol. $30, n^{\circ} .2$, págs. 75-89.

Girard, Alain (1963). Le journal intime. Paris: Presses Universitaires de France.

Guerrero, Claudio (2015), "Niños que lo han visto todo: Cuerpo, destrucción y vejez en la poesía de Gonzalo Millán", Estudios Filológicos, $\mathrm{n}^{\circ}$. 56, págs. 33-50.

Gusdorf, Georges (1948), La découverte de soi. Paris: Les Presses universitaires de France.

Hernández, Biviana (2008), "Gonzalo Millán y la subjetividad fragmentada del autorretrato", Estudios Filológicos, 43, págs. 115-130.

Hierro, Manuel (1999), "La comunicación callada de la literatura: reflexión teórica sobre el diario íntimo", Mediatika, 7, págs. 103-127.

Levinas, Emmanuel (2006). Totalidad e infinito. Salamanca: Ediciones Sígueme.

Lihn, Enrique (1989). Diario de muerte. Santiago de Chile: Editorial Universitaria.

Luque, Álvaro (2016), "El diario personal en la literatura: teoría del diario literario", Castilla. Estudios de Literatura, vol. 7, págs. 273-306.

Martínez E, Pacián (1984), "Gonzalo Millán: El exilio obliga al crecimiento, a volcarse hacia realidades nuevas", El Sur. Concepción: [s.n.], 1882- v., (6 mayo 1984), págs. 4-5 (suplemento)

Millán, Gonzalo (1968). Relación personal. Santiago de Chile: Arancibia Hermanos.

------ ---- (1997). Trece lunas. Santiago de Chile: Fondo de Cultura Económica.

(2002). Claro/Oscuro. Santiago: Ril Editores. 
(2005). Autorretrato de memoria. Santiago de Chile: Ediciones Universidad Diego Portales.

(2008). Veneno de escorpión azul. Diario de vida y de muerte. (Segunda edición). Santiago de Chile: Ediciones Universidad Diego Portales.

-------, -------- (2011). Gabinete de papel. (Segunda edición). Santiago de Chile: Ediciones Universidad Diego Portales.

Mistral, Gabriela (1960). Desolación. Buenos Aires: Espasa-Calpe Argentina, S. A.

Morales, Leonidas (2009). Formalismo y ambigüedad. Poesía chilena de los sesenta. Santiago de Chile: Editorial Cuarto Propio.

Muñoz, Enoc (2007), “'¡Mantente firme!'. Gonzalo Millán: poema y resistencia”, Cyber Humanitatis, $\quad$ n’. $\quad 42, \quad$ s/p. Disponible en:

https://web.uchile.cl/vignette/cyberhumanitatis/CDA/texto simple2/0,1255,SCID\%253D21063\%2526ISID\%253D7 $\underline{31,00 . h t m l \# \text { ftn } 1}$

Nancy, Jean-Luc (2006). La mirada del retrato. Buenos Aires: Amorrortu Editores.

Nómez, Naín (2010), "Exilio e insilio: representaciones políticas y sujetos escindidos en la poesía chilena de los setenta", Revista chilena de literatura, nº. 76, págs. 105-127.

Picard, Hans Rudolf (1981), "El diario como género entre lo íntimo y lo privado", en 1616: Anuario de la Sociedad Española de Literatura General y Comparada, vol. IV, págs. 115-122.

Roca Leiva, Macarena (2007), "Hibridación genérica en Gonzalo Millán. Lectura del diario íntimo Veneno de escorpión azul”, Acta Literaria, no . 40, págs.147-155.

Rodríguez, Mario (2002), “La galaxia poética latinoamericana. 2a mitad del siglo XX”, Acta Literaria, nº 27, págs. 91108.

Rojas, Waldo (1997), “Gonzalo Millán: acerca de su poesía reunida”, en Gonzalo Millán. Trece lunas. Santiago de Chile: Fondo de Cultura Económica.

Savater, Fernando (1986). El contenido de la felicidad. Madrid: Ediciones El País.

Sepúlveda, Magda (2013). Ciudad quiltra. Poesía chilena (1973-2013). Santiago de Chile: Editorial Cuarto Propio.

Sontag, Susan (2005), "El artista como sufridor ejemplar", en Contra la interpretación. Buenos Aires: Alfaguara.

Tesche, Paula y Noemí Sancho (2013), "Cuerpos agónicos: representaciones de la muerte en tres poetas chilenos", Literatura y Lingüística, nº. 26, págs. 101-113.

Valente, Ignacio (1980), "Dos poetas del exilio”, El Mercurio. Santiago, Talleres El Mercurio, (4 mayo), pág. E3.

Zaldívar, María Inés (1998). La mirada erótica: Gonzalo Millán / Ana Rosetti. Santiago de Chile: RIL Editores y Café Central Barcelona.

Zambrano, María (2006). Filosofía y poesía. México: Fondo de Cultura Económica. 